\title{
Education for Sustainable Development in Kenya: Rhetoric and Reality in Basic Education
}

\author{
Benard O. Nyatuka
}

\begin{abstract}
Education for sustainable development (ESD) is increasingly being recognized as a critical element of education systems and facilitator of sustainable development. This is because its ultimate goal is to foster ideal teaching, learning, policies and practices needed to enhance social, economic, ecological viability and well-being for the present and future generations. Embracing ESD could therefore, facilitate realization of objectives of the Competency-Based Curriculum (CBC) that Kenya has rolled out. Particularly, the CBC is expected to foster acquisition of core competencies like creativity, problem-solving, and self-efficacy. But, limited understanding, inappropriate pedagogical approaches, and weak collaboration among key stakeholders are some of the challenges that face application of ESD. This research review focuses on the pertinent ESD aspects to successful implementation of the CBC in basic education in Kenya. Specifically illuminated are the underpinning pedagogical theories and their implications, relevant legal and policy frameworks, some success stories, challenges and proposed solutions.
\end{abstract}

Keywords: Basic education, Competency-Based Curriculum, Constructivism, Education for sustainable development, Pedagogy

\section{Introduction}

Given that the world today is experiencing a great level of uncertainty, complexity and rapid change, embracing more sustainable intervention measures, including appropriate education about sustainable development is imperative. According to Sterling (2014) and UNESCO (2011), such global issues as economic instability, climate change, social inequity, loss of biodiversity and migration as well as non-renewable energy sources need to be addressed urgently. It is important to note, however, that sustainability is a highly demanding concept as it calls for changes at the political, social, economic, environmental, educational and decision-making levels, among others. Kondur, Ridei, Mykhailyshyn and Katsero (2020) argue that since education for sustainability is evolving on a geospheric, geopolitical and transboundary scale, it can be defined economically, socially, environmentally and educationally. On their part, Lampa, Greculescu and Todorescu

Full listing of authors and contacts can be found at the end of this article.
(2013) consider sustainable development to be a continuous search for improving our daily lives, while minimizing the negative impact brought about by humans on the environment. This requires active, creative and cooperative citizens who are able to successfully prevent and solve problems, and be ready to combine theoretical knowledge with innovations and practical ideas.

As a prerequisite for realizing sustainable development, education systems should be restructured to focus on enhancing the development of creative thinking among the population, promoting tolerance and democratic ideals, making informed decisions and participating in the implementation of relevant cross-cutting plans and issues (Kondur, et al, 2020; UNESCO, 2005a). In the European Union, for example, sustainable development is regarded to be the basic principle upon which all policies are anchored. Particularly, education service providers should develop programmes for sustainable education that balance future knowledge with traditional lifestyles. However, it should be borne in mind that such education is not aimed at changing 
people's lifestyles, but empowering and encouraging them to participate in sustainable development, including reflecting on their actions in this field.

UNESCO (2019) stipulates that by 2030, all learners should acquire the knowledge and skills needed to promote sustainable development. And, this is supposed to be achieved through, among others, education for sustainable development, sustainable lifestyles, human rights and gender equality. Other means are promotion of a culture of peace and nonviolence, global citizenship and appreciation of cultural diversity. Indeed, Lampa, Greculescu and Todorescu (2013) note that education for sustainable development is a broad movement concerned with identifying and advancing the kinds of education, teaching and learning policy and practice to ensure social, economic and ecological viability and welfare, now and into the long-term future. The authors hold that education for sustainable development aims at enhancing consciousness, ensure a coherent way of life with the principles of sustainable development, that is, being more informed, moral and responsible about the ability of future generations to meet their needs.

According to Ganira and Odundo (2018), the overriding theme of education for sustainable development is integration of values inherent in sustainable development into all aspects of curricula to encourage change in behaviour that alloys a just society for all. In addition to moral and ethical values, education for sustainable development has various dimensions, such as peace education, medical education, consumer education, among others (Fosnot, 2013; Armstrong, 2011). The main task of education for sustainable development therefore, is formation of a value-oriented personality directed towards socially, economically and environmentally significant values. Ganira and Odundo (2018) observe that integrating sustainable development strategies such as problem-based, inquiry-based, and reflective learning in teaching and learning should motivate learners to become responsible individuals who will solve challenges, respect cultural diversity and contribute to creating a sustainable society.

Armstrong (2011) contends that skills associated with education for sustainable development are expansive and include collaboration and cooperation, conflict resolution, creativity, imagination, future mindedness, knowledge transfer, meaningful communication and civic engagement. Others include interdisciplinary research skills, adaptive learning, contextualization of issues, personal introspection visioning, systems thinking as well as values focused teaching. To achieve these, all those involved in the delivery of education for sustainable development must practice what they preach (Fosnot, 2013). Thus, education for sustainable development requires approaches that reflect a paradigm shift from manual training of discipline-specific content to a focus on enhancing quality of life that is rich with intellectual and social capital. Indeed, the education for sustainable development pedagogy initiated by UNESCO (2004) highlights a shift towards active participation and experiential learning that engages the learner in thinking and accords them the ability to act responsibly.

Lampa, Greculescu and Todorescu (2013) note that education for sustainable development is central to preparing learners for lifelong learning, an adaptive quality that makes the learner more malleable in a time when most societies are experiencing dramatic social, environmental and economic transformation. In Armstrong (2011), concepts like deep learning, transformational learning, active learning, service learning and critical emancipatory pedagogy have all been included in pedagogical discussions about education for sustainable development.

With respect to Kenya, Opanda (2013) observes that four main ideas related to education for sustainable development have so far received heightened attention. These are improving access to basic quality education; restructuring of the present educational system; development of public understanding and awareness; and enhancing the quality of the teacher training programmes. In particular, teachers are extremely important drivers of change in the education for sustainable development. Ganira and Odundo (2018) assert that adoption of education for sustainable development pedagogies into the basic education curriculum requires appropriate teaching and learning methods that motivate and empower learners to modify behaviour and take actions for sustainable development. Given that education for sustainable development pedagogies facilitate learning of knowledge, skills, perspectives and values that sustainable societies entail, the researchers emphasize that appropriate pedagogies for sustainable development be used.

Through Sustainable Development Goal 4 (SDG 4), education for sustainable development provides a cross-cutting mechanism for the achievement of all the SDGs in Kenya (Ministry of Education, 2017). This is in line with Agenda 2063 of the African Union which calls for action on catalyzing education and skills revolution to build knowledge, human capital, capabilities and 
skills to drive innovations on the African continent. Addressing sustainable development challenges requires provision of quality education that offers competencies, values, knowledge and skills for sustainable living and prosperity. As an integral part of life-long learning, education for sustainable development is central to the delivery of quality education and necessary for capacity building of the Kenyan society for a green economy.

According to Wandabi (2019a), the Competency-Based Curriculum (CBC) provides an opportunity to nurture every learner's potential through quality education. This happens to be the ultimate goal of education for sustainable development. Just like education for sustainable development, the CBC seeks to empower learners to take informed decisions and responsible actions for environmental integrity, economic viability and just society for present and future generations, while respecting cultural diversity. Republic of Kenya (2017) holds that the teaching of values, especially at the basic education level, is expected to facilitate achievement of the curriculum reforms' vision, particularly with respect to developing ethical citizens. Specifically, basic education seeks to build capacities in learners that will enable them to be stewards of the earth, and minimize negative environmental impacts, while learning outcomes are linked to meaningful human, safety, educational, and environmental needs. The CBC endeavours to make learners work on real problems that make academic learning relevant while simultaneously enhancing their social skills, analytical ability, civic and ethical responsibility, self-efficacy, and career development (Wandabi, 2019a)

The CBC incorporates the pertinent and contemporary issues in society, including the related support materials. Education for sustainable development is one of such issues and focuses on environmental education, disaster risk reduction, safety and security education, financial literacy, poverty education, countering terrorism, extreme violence and radicalization, gender issues and animal welfare (Republic of Kenya, 2017). Accordingly, education should include values that support sustainable development such as care, respect, charity, social and economic justice, commitment, cooperation, compassion, self-determination and selfreliance. In the College Student Educators International (2008), change agents should possess such attributes as resilience, optimism, tenacity, commitment, passion, patience and emotional intelligence. Others are assertiveness, persuasiveness, empathy, authenticity, ethical self-awareness, competence and curiosity. The CBC emphasizes these attributes as well, as they are known to boost students' self-esteem (Republic of Kenya, 2017; Lampa, Greculescu \& Todorescu, 2013).

In the spirit of finding solutions to the challenges of sustainability of the biosphere and society in the country, the Ministry of Education has prioritized to focus on emerging gaps in the education sector (Ministry of Education, 2017). These include developing a relevant policy; transforming teaching, learning and training environments; building capacities of educators and trainers; and accelerating youth empowerment. This is in tandem with aspirations of Kenya's Vision 2030 development plan, the Global Action Programme on education for sustainable development and SDGs. Through the implementation of the education for sustainable development policy, the Ministry seeks to integrate such education into sustainable development policies and strategies of learning environments in training and learning institutions. This includes infusion of education for sustainable development into basic education, teacher training programmes and establishment of relevant youth-led initiatives.

Despite the efforts being made by the government, there appears to be a vague understanding of the concept of education for sustainable development among many citizens, use of inappropriate pedagogical methods and materials, and low level of collaboration among key stakeholders. On this basis, this research review examines the major aspects of education for sustainable development with intent to enhance their application. These aspects include the relevant pedagogical theories and their implications, legal and policy provisions and some success cases. Also, discussed are critical challenges and possible remedies.

\section{Theoretical Framework}

According to Fosnot (2013) and Armstrong (2011), education for sustainable development may be better understood by exploring constructivism theories which are characterized by high levels of learner engagement, including active, applied, service and experiential learning. Such theories also lay emphasis on social interaction that involves problem-based, inquiry-based, as well as participatory learning. . Constructivism theories hold that human beings construct all knowledge while participating in different mental and physical experiences (Kalsoom, 2019; Republic of Kenya, 2017;). Thus, constructivism is a supposition about the nature of knowledge and how individuals acquire it.

In constructivism, the learner builds a personal 
interpretation of the world on the basis of experiences and interactions. Among the proponents of constructivism are Dewey's Social Constructivism, Vygotsky's Social-Cultural Development Theory and Gardner's Multiple Intelligence Theory. Others are Piaget's Cognitive Development Theory, Bruner's Cognitive Development Theory and Erikson's Theory of Psychosocial Development (Republic of Kenya, 2017). Tobias (2009) observes that other than extending both behavioural and cognitive theories about learning, constructivism includes contextual issues, like previous knowledge and experience, in the construction of knowledge. In this light, knowledge does not reside only in the mind but is situated in the context of an individual's past experience, beliefs and values, their cognitive process, and their environment (Schunk, 2008).

The core assumptions of constructivism are that learner activities lead to the creation of their own knowledge rather than mere acquisition of the same, and that truth is an evolving premise (Schunk, 2008; Simpson, 2002). Schwartz, Lindgren and Lewis (2009) and Tobias (2009) hold that active engagement leads to a higher understanding that may be applied to new and different situations. Armstrong (2011) asserts that three primary perspectives underpin constructivism, that is, endogenous, exogenous, and dialectical. Endogenous constructivism emphasizes internal cognitive processes, new knowledge being dependent on previously developed mental structures. This perspective connotes a highly active learning environment in which learners are able to explore and experiment through a variety of activities that motivate them to assimilate and accommodate what is learnt. The classroom is active with problem-solving engagements, rather than direct instruction. Teachers are discouraged from interjecting outcomes for the learners before they are able to invent on their own, taking a peripheral role until fundamental discoveries are concretized (Fosnot, 2013; Armstrong, 2011). Thus, the teacher's role is to create an environment suitable for such discovery. Likewise, peer interaction is an important means of discouraging egocentrism among the learners (Piaget, 1970; Tuckman, 1992; Wadsworth, 1978).

On its part, exogenous constructivism emphasizes the influence of the external world on the construction of knowledge, such as instruction, experience and use of models in the learning environment (Kalsoom, 2019; Armstrong, 2011; Shunk, 2008). It seeks to explain behaviour and the learning environment, including emphasizing the use of impressionistic models. The learner continuously adapts to, as opposed to copying, the structure in the environment and is responsive to contextual issues. The assumptions of the exogenous perspective are that interactions between the learner's cognition and other personal factors like biology, self-efficacy, and self-regulation, their environment as well as behaviour are reciprocal. Also, learning may occur by observing models, live or static, rather than as a result of feedback or behaviour. Bandura (1989) advocated for highly knowledgeable and effectual teachers who are able to motivate while also developing important cognitive abilities among learners.

Dialectical constructivism is positioned centrally between the endogenous and exogenous perspectives, emphasizing the contextual nature of the construction of knowledge. Armstrong (2011) and Simpson (2002) assert that dialectical constructivism is particularly useful in informing the pedagogical implementation of education for sustainable development. This perspective is especially responsive to the complex, uncertain and values-laden nature of sustainability. Both a dialectical perspective of constructivism and education for sustainable development champion for iterative reflection, supporting Vygotskys's (1978) contention that social interaction precedes internal reflective processes, thereby reinforcing cognitive development and learning that happens post-interaction (Bonnett, 2003).

Armstrong (2011) advises that implementing education for sustainable development will remain impossible without the commitment by educators to the new paradigm. Wals (2010) notes that learning strategies that emphasize dialogue and cooperative experiences are quite useful in the delivery of education for sustainable development as they promote pluralism and incorporation of prior perceptions with new meaning. In the provision of education for sustainable development, a teacher or educator is a facilitator, collaborator and fellow learner on the journey towards sustainability. Such a teacher allows the learner to direct their own learning and guide course content, although this does not necessarily indicate relinquished control or authority.

\section{Implications of the constructivism theories on ESD pedagogy.}

Apparently, the pedagogical approaches used in education for sustainable development are considerably oriented to a constructivist epistemology. Among others, it is important to design experiences that match the developmental level of the learner, especially those that encourage learning activities that go just beyond 
their capacities (Fosnot, 2013; Armstrong, 2011). The lived experiences, community, active engagement and collaboration in education for sustainable development strategies assert the belief that there is magic in social interaction with peers, teachers and industry partners. Accordingly, some of the common strategies for the development of relevant skills are collaborative activities, systems instruction, multigenerational analysis, problem-based assignments, inquiry and action research (Fosnot, 2013). Others are stakeholder analysis, role play, offering multiple perspectives in topics, back-casting and scenario building.

The approach to education for sustainable development, especially with respect to teaching and learning should focus on students, encouraging them to form and develop their own ideas and values. Teachers should consider pupils as being an important and active factor in learning. Lampa, Greculescu and Todorescu (2013) assert that active listening, assuming of responsibilities and solidarity are considered prerequisites to successful relationships based on social cooperation and interaction among pupils and people in general. Hence, it is necessary for teachers to develop these competencies during their didactic activity.

Likewise, educational experiences need to be made interdisciplinary or multidisciplinary with a view to exposing the learner to different social configurations. It should be appreciated that pedagogies like service, participatory and experiential learning are characterized by collective inquiry and problem-solving that require learners to dialogue with others around them, thereby facilitating the discovery of new meanings collectively (Fosnot, 2013; Armstrong, 2011). Capacity building, values development and cooperative relationships are fostered in such an educational environment. Learners should be encouraged to be interdependent upon one another to continuously amend the truth with higher degree of precision, inviting emergent outcomes.

Pedagogical competence should be understood as a synthesis of cognitive, visual, practical and personal experience (Kondur, et al, 2020). It is therefore, important to involve teachers in the relevant management processes in order to constantly improve the organization of decentralization of education. Future educators need to develop general knowledge of the content of sustainable development, ability to combine content of different disciplines in terms of social and cultural context and learn to overcome uncertainty. On their part, students need to think critically; respond to different situations appropriately; resolve conflicts; work as a team; and, develop responsibility and autonomy. These are all considered to be tools of strategic thinking. Since education for sustainable development issues are controversial and complex, learners should be able to manage them as well as the disagreements among themselves and relevant participants. Sustainable education encourages both teachers and students to use creative thinking, share ideas, cooperate and make decisions. Hence such a school is dynamic, no longer dictated by traditional hierarchical structures. The educational process should be such that even the weakest students are educated in a manner that their actions, present or future, pose no danger to society or even themselves (Lampa, Greculescu \& Todorescu, 2013).

There is need to rethink educational policies for sustainable development that aim at developing social, economic and environmental knowledge that will ultimately assist students in tackling challenges of modern life. Also, there is need for partnerships among institutions to provide teachers with efficient training programmes; ensure multicultural contexts to help them understand diversity and practice tolerance towards others, work closely with parents, colleagues and the community; reflect and improve upon their didactic activity as far as education for sustainable development is concerned (Lampa, Greculescu \& Todorescu, 2013; Armstrong, 2011).

And, to ensure the quality of didactic activity in sustainable development, teachers should acquire and develop competences and abilities based on not only formal, but also informal and non-formal dimensions, and have them officially recognized. This includes identifying each pupil's specific needs and working towards meeting them by use of a wide range of teaching strategies. It also involves helping pupils to develop professional and cross competences (Lampa, Greculescu \& Todorescu, 2013).

Venkataraman (2009) as well as Rode and Michelsen (2008) note that the development of assessment methods in education for sustainable development is a substantial area of opportunity. UNESCO (2005b) makes audible the need for assessments that not only pay attention to knowledge competency, but skills, perceptions, behaviours and values as well. Specifically, standardized testing is dissuaded, while methods that speak to a holistic view of the overall quality of education are encouraged. This is in line with the CBC which among others, advocates for assessment that determines the capability to apply a set of related knowledge, skills, values and abilities required to 
successfully perform critical work functions or tasks in a defined setting (Republic of Kenya, 2017).

In addition to the above theoretical implications on ESD pedagogy, the way forward is highlighted later in this piece of work.

\section{Legal and Policy Provisions on ESD in Kenya}

Key UN conferences, Acts of Parliament and related policy documents have played an important part in mobilizing both the international and local communities towards sustainable development (Sterling, 2014; Opanda, 2013; UNESCO, 2011; UNESCO, 2010; UNESCO, 2009a). In particular, the United Nations Conference on Environment and Development (UNCED, 1992) called for all countries to develop education for sustainable development strategies and frameworks to reorient education systems and programmes. The major thrusts to foster such education included improving basic education; and to develop public understanding, awareness and training (Opanda, 2013). In 2002, the United Nations Decade of Education for Sustainable Development (DESD) was mooted to facilitate implementation of such education (UNESCO, 2002; UNESCO, 2003).

In 2014, UNESCO launched a roadmap for implementing the Global Action Plan (GAP) on education for sustainable development. Based on this, Kenya's Ministry of Education has made commitment on this initiative through developing an education for sustainable development implementation strategy across all sectors. The strategy is to be guided by three broad objectives, that is, enhance the role of education and learning for equitable, efficient and sustainable utilization of the country's resources; promote quality education through diverse learning and public awareness for improved quality of life and productive livelihood; and promote teaching and learning that inculcates appropriate values, behaviour and lifestyles for good governance and sustainability.

The 2013-2018 National Education Sector Plan presents a strategy for education and training to promote education for sustainable development with reference to the UN GAP programme. This led to the development of education for sustainable development policy for the education sector in 2017 (Wandabi, $2019 b$ ). The policy focuses on providing, promoting and coordinating quality lifelong education, training, research and innovation for Kenya's sustainable development. Albeit various hurdles, partnerships, collaborations and networks have been formed to enhance education for sustainable development implementation
(UNESCO, 2009b).

In tandem with the $\mathrm{CBC}$, the education sector policy on education for sustainable development promotes competencies such as critical thinking, creativity and making decisions in a collaborative way. It is indicated that this is to be realized through integrating sustainable development into education and vice versa (Ministry of Education, 2017). Its implementation is particularly to be done in the different education levels that include basic education; higher education; teacher and technical and vocational training institutions and workplace; lifelong learning and non-formal education.

Kenya's Vision 2030 development blueprint proposes policy formulation and curricula reviews to address education for sustainable development (Republic of Kenya, 2007). The national agencies are expected to play a key role in leading as well as supporting learning opportunities for change towards sustainable development across sectors. In Kenya, the education for sustainable development national implementation strategy uses capacity-building, advocacy, vision-building, partnerships and co-ordination as key approaches to achieve this (UNESCO, 2011). The medium-term plan (2008-2012) for Vision 2030 requires that all training institutions' curricula are re-oriented to address sustainable development issues. Already, the development of a life skills curricula has been done by the Ministry of Education while teachers and education officers have been trained and involved in delivering the same syllabus across the country (Wandabi, 2019a).

Among other notable initiatives, the education sector has increased financial support for capacity development activities and strengthened the Kenya Education Management Institute, the agency for building capacities for education managers. Similarly, the Centre for Mathematics, Science and Technology Education in Africa (CEMASTEA) has been offering pedagogical leadership training to support teachers in implementing effective and innovative classroom practices concerning education for sustainable development (Wandabi, 2019b). Particularly, it has been sensitizing education and quality assurance officers and other stakeholders on effective management of sustainable and institutionalized in-service education and training of teachers.

The Environmental Management and Coordination Act (1999), Cap 387 provides for effective coordination and regulation of all actions that have a direct influence on the environment in Kenya (Wandabi, 2019b). Similarly, Section 69 (2) of the Constitution of Kenya stipulates that every person has a duty to cooperate with the

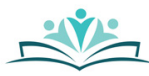


relevant national organizations and other stakeholders to protect and conserve the environment (Republic of Kenya, 2010). This involves ensuring that an ecologically sustainable development and use of natural resources is promoted. In the National Environment Management Authority (NEMA, 2008), the Kenyan strategy provides status, communication, facilitative and result indicators to monitor the implementation of education for sustainable development at all levels. As a result, awareness on this venture has steadily increased over the years.

On its part, Section 42(4) of the Basic Education Act focuses on the promotion of environmental protection, especially education for sustainable development (Republic of Kenya, 2013). Sessional Paper No.4 of 2012 on Reforming Education and Training in Kenya envisaged a curriculum that is competence-based to foster quality education and enhance the integration of education for sustainable development at all levels of education in the country (Republic of Kenya, 2017). Indeed, Kenya has already rolled out a new competency -based curriculum for primary and secondary schools. The curriculum has sections that deliberately show how education for sustainable development can be integrated into the curriculum as a pertinent and contemporary issue (Wandabi, 2019b).

Furthermore, the government has developed a Green Economy Strategy and Implementation Plan (GESIP, 2016) to address sustainable development challenges to achieve its long-term development goals as defined in Vision 2030 (Ministry of Education, 2017). This policy is to enhance the implementation of education for sustainable development across sectors to enhance the attainment of the SDGs by improving quality of education, building capacity at all levels and enhancing public understanding and awareness of the sustainable development agenda. Accordingly, the 17 SDGs provide the wider context for further up-scaling and mainstreaming education for sustainable development in the country.

As a guide to the implementation of the $\mathrm{CBC}$, the government developed the Basic Education Curriculum Framework (Republic of Kenya, 2017). The framework is anchored on values and provides a comprehensive conceptualization of reforms in basic education, including pre-primary education, primary, secondary and inclusive education. This is important since values influence how we feel, act and make choices in life. This thrust is meant to nurture learners who do the right thing at any given time. In spite of the various documents focusing on education for sustainable development, its level of implementation is wanting, especially at the basic education level in Kenya. Among others, this research review has made a deliberate attempt to consolidate such works for easy reference and application.

\section{Some Success Cases of ESD in Kenya}

A number of measures have been undertaken by various stakeholders to enhance education for sustainable development, especially in the basic education institutions in Kenya. One such initiative is the Ecoschools, an international programme founded in 1994 and run by the Foundation for Environmental Education (Kenya Organization for Environmental Education, 2020). Among others, it sponsors an environmental action-based learning in primary and secondary schools as a tool for development. Learning is project-based and promotes creativity, critical thinking and problem-solving. The Eco-Schools and the foundation are lead partners in UNESCO's Global Plan for education for sustainable development (Andreou, 2016). Implemented in 60 countries worldwide (Kenya Organization for Environmental Education, 2020), its mission is to empower students to be the change a sustainable world needs through fun and action-oriented activities.

According to Andreou (2016), the programme aims at achieving educational goals as well as sustainable development through schools as entry points to communities. This has been implemented in Kenya since 2003, growing from a pilot of 12 schools, to over 1,000 primary and secondary schools across the country as at 2020. The pilot phase was based on five key components of environmental action learning, namely environmental policy; cross-curriculum teaching and learning; micro-projects; school-community partnerships; and networks. Funded by the Danish International Development Agency and implemented in partnership with the Danish Outdoor Council, the main focus themes were water, sanitation and hygiene, energy, healthy eating, sustainable agriculture, climate change, biodiversity and waste management. The cross-cutting themes included HIV/AIDS, global citizenship, entrepreneurship, and disaster preparedness and management (Wandabi, 2019b).

The Kenya Organization for Environmental Education (KOEE) has produced relevant theme packs for teachers and learners, developed teacher guides, a teacher training manual and a handbook (Wandabi, 2019b) ). In UNESCO (2011), the Eco-Schools 
programme in Kenya seeks to empower the youth, women and the poor; raising public understanding and awareness of sustainability; and training in education for sustainable development. The relevant projects take place through participation of multiple stakeholders, including government, civil society and private sector. In particular, strategies used by schools to boost sustainable development include advocacy, campaigns and vision building, capacity building, teacher training, monitoring and evaluation, and creation of school-community partnerships for purposes of ownership of such activities.

Andreou (2016) observes that the Eco-Schools programme provides a framework and standards to help educators integrate sustainability principles throughout their schools. These principles are to ensure that participants are: engaged in the learning- teaching process; empowered to take informed decisions and actions on real life sustainability issues; encouraged to work together actively and involve their communities in collaborative solutions; supported to examine their assumptions, knowledge and experiences in order to develop critical thinking; and to be open to change. Other principles are to encourage participants to be aware of cultural practices as an integral part of sustainability issues; encourage sharing inspirational stories of their achievements, failures and values to learn from them, and to support each other; continuously explore, test and share innovative approaches, methodologies and techniques; and ensure continuous improvement through monitoring and evaluation of the programmes. The programmes offer methodological tools for schools and communities to evaluate their own challenges; assess risks and develop the solutions. Most importantly, the schools are guided to re-orient existing curricula around sustainable development themes, and work collaboratively with their local communities to develop practical projects.

The Indian Ocean Programme is a regional framework to integrate themes of sustainable development, climate change and risk reduction into national education systems, and strengthen cooperation to address the unique vulnerabilities of the region (Andreou, 2016). It involves 72 Eco-Schools, with a population of at least 25,000 students. Activities at school include food production, rainwater harvesting, soil stabilization, sanitation and waste management. It is reported that the most successful schools are those that have built strong partnerships between governmental institutions, NGOs, and the private sector. Among others, this is particularly important in addressing the damaging day-to-day effects of climate change that include rise in sea level, soil erosion, flooding, water shortages and high frequency of natural disasters.

The Eco-schools programme in Kenya particularly responds to the Green Economy Agenda through promotion of green enterprise development in schools and community (Wandabi, 2019b). Initiated by the Kenya Organization for Environmental Education and other partners, the project seeks to transform schools into models of sustainability for communities. Its main objective is to inculcate a greening culture to youth in schools by mentoring and engaging them in hands-on green growth initiatives for sustainability of communities. The project has been implemented in a dozen primary schools from Kwale, Makueni, Embu, Kirinyaga, Bomet and Kisumu Counties. A teacher's guidebook on green enterprise development for schools in Kenya was developed in consultation with teachers from schools participating in the Schools Green Challenge Project, the Ministry of Education and the Royal Danish Embassy in Kenya.

Similarly, the Kenya Organization for Environmental Education has implemented a sustainable Water, Sanitation and Hygiene (WASH) project under the Eco-Schools programme in Vihiga County. The goal is to improve access and reliable safe water in schools and community (Kenya Organization for Environmental Education, 2020). The project entails sinking simple wells to enhance provision of water to ensure accessible safe water in schools; installing water harvesting tanks in the schools to have a water harvesting system; building the capacity of school communities by installing a hand wash point in each of the participating schools; and building capacity of communities to practice sustainable water management, sanitation and hygiene through training.

The Eco-Schools Litter Less Campaign Project aims at reducing waste and foster long-term positive behaviour change among the youth (Kenya Organization for Environmental Education, 2020). Over 45 schools, 3,000 students and 200 teachers have so far been involved in the campaign in Kenya. The main objective is to raise awareness of the effect of litter on the local environment and wider community, increase student knowledge and practical skills in preventing and managing litter. It also seeks to enhance collaboration with other schools to promote education for sustainable development and influence others by communicating with them through multimedia platforms and other 
channels. The relevant campaign activities include waste management within and around the schools involved; community action days for schools to showcase their work to the surrounding community; and joint communication campaigns by schools through social media platforms to create awareness on issues of waste management. More recently, the Kenya Organization for Environmental Education has teamed up with other partners to promote plastic recycling through EcoSchools (Wandabi, 2019b).

Also, the Eco-Schools programme introduced a value-based approach to promoting education for sustainable development, and as a measure to enhance sustainability as a whole (Kenya Organization for Environmental Education, 2020). Among others, it aims at delivering quality education that imparts knowledge, skills, attitudes and values from religious teachings. These are considered as instruments for entrenching faith-based values into education for sustainable development in schools, while promoting action for the environment with faith as the motivation. To date, a total of 50 schools have been involved in the initiative. The project produced a faith-based education for sustainable development teachers' toolkit for schools that illustrated an approach of solving a society's development issues using faith. According to the Republic of Kenya (2017), the country has been putting emphasis on approaches that promote whole institution development of education for sustainable development. The Eco-School programme is considered to be an effective whole institution approach in mainstreaming sustainability into all aspects of the learning environment.

In conjunction with MASHAV, a Hebrew acronym for Israel's Agency for International Development Cooperation, Kenya's Ministry of Education and the Kenya Secondary Schools Heads Association established a joint project directed towards the promotion and implementation of education for sustainable development, to become an integral element in curricula of learning institutions (MASHAV, 2013). The ultimate goal of the joint project is to establish a national network of education for sustainable development in the country, including setting up demonstration centres which will serve as a source of training for the remaining school. One of the principles is 'Think Global, Act Local', meaning that awareness of the global crisis is important but action should be taken at the local level. The model provides schools and the community with the necessary tools for assessing their actual needs and existing resources. This model was launched in August 2013 at the Joel
Omino secondary school in Kisumu County. It includes teaching as well as learning technology, science, history and democracy, among others. This has successfully been applied in water purification; organic agriculture; economics and entrepreneurship, including establishment of an organic bakery; knowledge of building traditional houses; and utilizing recycled materials for art work.

The WWF-Kenya organization has made effort to integrate sustainable development into teaching and learning in basic education institutions by inculcating participatory pedagogical methods (WWF-Kenya, 2020). In particular, the organization's marine programme works with schools in the country's coastal region to promote education for sustainable development. Interactions are through discussions, lectures, presentations and mentorship. The successful projects implemented by schools include establishment of school gardens, tree planting and engagement in community service, for example, beach clean-up exercise on both the World Environment Day and International Coastal Clean-up celebrations. In addition, the organization continues to offer scholarships for girls from poor backgrounds within the islands surrounding Lamu County and its environs.

Furthermore, the Wildlife Clubs of Kenya have published an environmental education resource book for teachers and learners of primary and secondary schools, while Nature Kenya has produced an education for sustainable development resource book for both students and teachers called 'Learning for Sustainable Living in Kenya' (Wandabi, 2019b). Apart from these organizations, many NGOs are involved in offering skills-focused training for community-based innovations involving marketing, product sales and sustainability. The African Fund for Endangered Wildlife in Kenya provides training to school children, teachers and community groups on environmental conservation.

But, given that only a few primary and secondary schools have made laudable efforts with respect to embracing education for sustainable development means that much more requires to be done by the various stakeholders to bring the rest of the institutions on board. Indeed, making such a move is quite crucial in order to achieve the objectives of this pedagogical paradigm shift as well as the Competency-Based Curriculum, especially at the basic cycle of learning in Kenya. In the following section, an elaborate discussion on challenges facing education for sustainable implementation in Kenya, as well as possible solutions is made. 


\section{Challenges Facing ESD and Proposed Solutions.}

Although sound education for sustainable development serves as a panacea for most of the pedagogical, environmental and socio-economic issues we contend with today, there are many challenges that require to be addressed so as to realize the desired outcomes. Armstrong (2011) opines that education for sustainable development offers a renewed vision for educational policy and practice fully in tune with the needs and issues of the 21st Century. Unfortunately, the concept of education for sustainable development is yet to be fully understood by many stakeholders in Kenya (Wandabi, 2019a), leave alone the few experts in this area to facilitate the appropriate processes of teaching, learning, creating awareness and understanding education for sustainability (UNESCO, 2019). Due to this, the development of adequate and relevant materials still remain a challenge. This calls for the various networks of experts as well as interested groups to enhance and strengthen the capacity-building processes.

According to Sterling (2014), the key role in realizing sustainable development is often ignored, downplayed or under-estimated. Often, it is viewed in isolation from the other instruments of change. In the sustainable development debate therefore, embracing appropriate education should always be emphasized. Despite the success of the international initiatives in this front, there are instances where much sustainable development discourse and policy underplay the role of education, and vice versa.. Essentially, sustainable development should be embedded in basic education such that there is both mutual benefit and accelerated positive effect, sufficient to win breakthrough towards an economically secure, ecologically stable and socially just society.

Opanda (2013) asserts that the limited progress in the provision of education for sustainable development is partly due to lack of vision, awareness, policy framework and funding. Notably, there is little effort that has been strategically made to mainstream sustainable development in teacher education programmes, especially at the basic education level. Hence, there is a gap in both the body of knowledge and actual practices of many teacher educators in this area. Yet, the contribution of teacher trainers is key in the delivery of the same. According to Armstrong (2011), pedagogical innovation has been slower to develop. This calls for appropriate intervention measures.

Wandabi (2019b) notes that there is little evidence of attention or investment in the capacity-building of educators, facilitators or curriculum developers with regard to education for sustainable development. Armstrong (2011) observes that this scenario is worsened by the nature of integration of education for sustainable development that is often complex, while the curricula is examination-oriented and overloaded with content as well as learning outcomes. Thus, the weak integration of education for sustainable development, especially in basic education needs well designed pre-service and in-service teacher training programmes.

Ganira and Odundo (2018) observe that emphasis is often given to the cognitive domain rather than the affective and psychomotor ones, thereby undermining the purpose of education for sustainable development. Additionally, UNESCO (2011) holds that whereas sustainable development has been partially embedded in the formal education institutions, there is little attention being paid to the non-formal and informal curricula. Also, the pedagogical approaches used in the different educational settings are often inappropriate.

The lack of synergy between education for sustainable development activities sometimes leads to duplication of certain initiatives like teacher training and inefficient use and development of relevant resources (UNESCO, 2011). Again, innovations from the community-based organizations and other small groups in society do not always get adequate support for their projects. Partially, this is a result of government bureaucracy and lack of resources in implementing this kind of education. Furthermore, UNESCO (2011) reports that most community-based organizations have not been able to influence policy in the country due to lack of education for sustainable development awareness and commitment. Other challenges are to do with bridging the gap between what happens at home and what is taught in schools; pressure on teachers within the workplace; linking infrastructural change to the mindset change and strengthening community engagement (Milne, 2019).

In particular, Kenya's Competency-Based Curriculum, which considers education for sustainable development as a critical contemporary issue, has experienced challenges to do with its implementation. These range from inadequate teacher training through poor infrastructure to huge budgetary implications. Worth noting is that some of these challenges revolve around poor governance, corporate irresponsibility, lack of accountability, inefficient and wasteful production systems. Such challenges usually lead to unsustainable utilization of the natural resources, resulting into their 
degradation (Wandabi, 2019b). Milne (2019) argues that there is need to have ethos in schools that openly and enthusiastically support education for sustainable development. Clearly, this partly goes down to the curriculum that schools follow, and the interest and effort shown by the senior management in promoting such integration.

Milne (2019) concludes that to attain education for sustainable development, there should be both the physical as well as mindset changes. The physical change involves examining how schools, households and businesses can reduce, say, their waste, conserve water and energy and focus on more sustainable responses in general. On the other hand, the mindset change involves raising environmental understanding, awareness and action programmes through workshops and cross-curricular activities meant to give employees and learners a voice. Indeed, taking such relevant steps will go a long way towards strengthening the provision of ESD in basic education.

\section{The Way Forward}

To create a world that is more just, peaceful and sustainable, all individuals and societies must be equipped and empowered by knowledge, skills and values as well as heightened awareness to drive such change. This includes learning to respect others and appreciating the environment, as well as giving back to society. This could be achieved through relevant seminars, workshops, resources and activities, whether at home, school or community. To enhance the success of such initiatives, preparation of carefully designed action plans to facilitate application of ESD, particularly in basic education is paramount.

Since teacher education is a critical aspect to be considered, there is need to bolster inclusion of sustainable development in the teacher education programmes. Such training should include appropriate content, pedagogy as well as development and acquisition of the necessary resources. Milne (2019) emphasizes that with trained and motivated teachers, it is far easier to inspire and motivate learners.

Critical thinking, imagination, learning to learn, communication and collaboration, are among the core competencies emphasized in the basic education curriculum in Kenya. Although the CBC is designed to achieve these, there is need for strong partnerships and more participatory evaluation mechanisms to enhance the quality of education for sustainable development programmes.

\section{Conclusion}

Like the rest of the countries in the globe, sustainable development issues in Kenya are complex, dynamic and interlinked. Embracing sustainable development and global citizenship education are considered to be the main solutions to these challenges. The latter entails peace and human rights education, intercultural education and education for international understanding. In particular, these should include the aspects of shaping the quality of training of specialists and humankind, using formal, non-formal, inclusive and democratically oriented models of education and science (Kondur, et al, 2020). Accordingly, countries should promote the availability of educational tools, teaching aids and textbooks for sustainable development to all who need them. But to achieve this, synergy among the initiatives taken as well as greater support from the various stakeholders is paramount.

Indeed, Sterling (2014) advises that unless the various stakeholders, including policy-makers, legislators, businesses, the media and civil society are involved in learning processes, the SDGs cannot be achieved. Education can enhance the effectiveness of each of these instruments through developing informed engagement, agency and empowerment among all the affected stakeholders. It can also build lasting change, because it is owned by the learner and touches both the heart and mind.

Although Kenya has made some milestones in rolling out a competency-based curriculum in the basic education institutions, there are still many challenges that need to be addressed in order to successfully implement it. These include producing the relevant education for sustainable development pedagogical materials, enhancing professional capacities, promotion of research, strengthening cooperation, communication and partnerships and the establishment of monitoring and evaluation processes. Going forward, formulation of action plans for implementation and appropriately training both present and future professionals in all sectors should be based on the basic ideas of education for sustainable development. 


\section{References}

Andreou, N. (2016). Education for sustainable development from schools to communities. Copenhagen, Denmark: Foundation for Environmental Education.

Armstrong, C . M. (2011). Implementing education for sustainable development: The potential use of time-honored pedagogical practice from the progressive era of education. Journal of Sustainability Education, 2, 1-25.

Bandura, A. (1989). Social cognitive theory. In R. Vasta (Ed.), Annals of Child Development, 6, Six Theories of Child Development, 1-60. Greenwich, CT: JAI Press.

Bonnett, M. (2003). Education for sustainable development: Sustainability as a Frame of mind. Journal of Philosophy of Education, 37(4), 675-690.

College Student Educators International. (2008). Toward a Sustainable Future. American College Personnel Association.

Fosnot C. T. (2013). Constructivism: Theory, perspectives, and practice. New York: Teachers. College Press.

Ganira, L. K \& Odundo, P. A (2018). Integrating dducation for sustainable development pedagogy in the pre-school social studies curriculum in Kenya: Review of literature. Paper presented at the International Conference on Research and Innovation in Education, Nairobi. October 24-26, 2018.

Kalsoom, Q. (2019). Constructivism and sustainable development. In: L. Filho W. (eds) Encyclopedia of Sustainability in Higher Education. Springer.

Kondur, O., Ridei, N., Mykhailyshyn, H., \& Katsero, O. (2020). Formation of competences of future educators for requirements for education for sustainable development. Journal of Vasyl Stefanyk Precarpathian National University, 7(1), 7-14.

Lampa, I., Greculescu, A., \& Todorescu, L. (2013). Education for sustainable development - Training the young generation for the future. Procedia-Social and Behavioural Sciences, 78, 120-124.
Israel Agency for International Development Cooperation. (2013). Education for Sustainable Development in Kenya. MASHAV.

Milne, P. (2019). Education for sustainable development: Key challenges. EcoMENA.

Ministry of Education. (2017). Education for sustainable development policy for the education sector. Nairobi: UNON Publishing Services.

Moshman, D. (1982). Exogenous, endogenous, and dialectical constructivism. Development Review, 2, 371384. National Environment Management Authority. (NEMA, 2008). Education for sustainable development implementation strategy. Nairobi: NEMA.

Opanda, J. (2013). Sustainable development in Teacher Education and Professional Development (TEPD) programmes in Kenya: A missing component. $\mathrm{Mu}-$ nich: GRIN Verlag,

Piaget, J. (1970). Piaget's theory. In P. H. Mussen (Eds.), Carmichael's Manual of Child Psychology, (pp. 703732). New York, NY: John Wiley \& Sons, Inc.

Republic of Kenya. (1999). Environmental Management and Co-ordination Act, CAP 387. Nairobi: National Council for Law Reporting.

Republic of Kenya (2007). Vision 2030. Nairobi: Government Printer.

Republic of Kenya (2010). The Constitution of Kenya. Nairobi: Government Printer.

Republic of Kenya (2013). The Basic Education Act. Nairobi: Government Printer.

Republic of Kenya (2017). Basic Education Curriculum Framework. Nairobi: Kenya Institute of Curriculum Development.

Rode, H. \& Michelsen, G. (2008). Levels of indicator development for education for sustainable development. Environmental Education Research, 14(1), 19-33. 
Schunk, D. H. (2008). Learning theories: An educational perspective. New Jersey: Pearson Merrill Prentice Hall (5th Ed).

Schwartz, D. L., Lindgren, R. \& Lewis, S. (2009). Constructivism in an age of non-constructivist assessments. In S. Tobias \& T. M. Duffy (Eds.). Constructivist Instruction: Success or Failure? (pp. 34-61). Routledge/Taylor \& Francis Group.

Simpson, T. L. (2002). Dare I oppose constructivist theory? The Educational Forum, 66(4), 347-354.

Sterling, S. (2014). The importance of education for sustainable development. University World.

Tobias, S. (2009). An eclectic appraisal of the success or failure of constructivist instruction. In S. Tobias \& Duffy, T.M. (Eds.). Constructivist Instruction: Success or Failure? (pp. 335-350). New York, NY: Rutledge.

Tuckman, B. T. (1992). Educational psychology: From theory to application. Fort Worth, TX: Jovanovich College Publishers.

United Nations Conference on Environment \& Development (UNCED, 1992). Agenda 21: Programme of Action for Sustainable Development. Rio Declaration on Environment and Development., Rio de Janeiro.

United Nations Educational, Scientific \& Cultural Organization (UNESCO, 2002). Education for sustainability. From Rio to Johannesburg: Lessons Learnt from a Decade of Commitment. World Summit on Sustainable Development, Johannesburg, 26 August-4 September, 2002. Paris.

UNESCO (2005a). The UN Decade of Education for Sustainable Development (2005-2014): International Implementation Scheme. Paris: UNESCO.

UNESCO (2005b). Contributing to a more sustainable future: Quality education, life skills and Education for Sustainable Development. Paris: UNESCO.

UNESCO (2009a). Bonn Declaration. UNESCO World Conference on Education for Sustainable Development, 30 March-2 April 2009. Bonn.
UNESCO. (2009b). Review of contexts and structures for Education for Sustainable Development, Paris: UNESCO.

UNESCO. (2010). UNESCO Strategy for the second half of the decade of Education for Sustainable Development. UNESCO.

UNESCO. (2011). National journeys towards Education for Sustainable Development: Reviewing experiences from Kenya. Paris: UNESCO.

UNESCO. (2019). Sustainable Development Goal 4 (SDG 4). Paris: UNESCO.

Venkataraman, B. (2009). Education for sustainable development. Environment Magazine, 51(2), 8-10.

Vygotsky, L.S. (1978). Mind in society. Cambridge, MA: Harvard University Press. Wadsworth, B.J. (1978). Piaget for the classroom teacher. New York, NY: Longman, Inc.

Wals, A. J (2010). Relativism, uncertainty and democracy in Environmental and sustainability Education. Environmental Education Research, 16(1), 143-151.

Wandabi, D (2019a). Kenya's new curriculum mirrors Education for Sustainable Development. Nairobi: Kenya Organization for Environmental Education.

Wandabi, D (2019b). Education for Sustainable Development in Kenya. Nairobi: Kenya Organization for Environmental Education.

World Wide Fund for Nature-Kenya (2020). Education for Sustainable Development: Why Does it Matter? WWF.

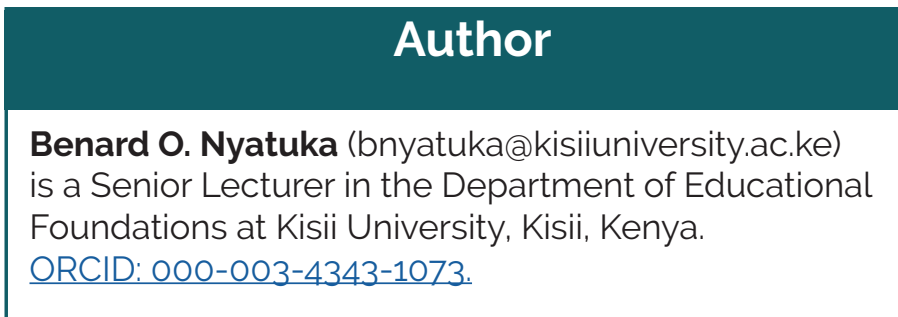

